\title{
Microbiota of Sardinian Goat's Milk and Preliminary Characterization of Prevalent LAB Species for Starter or Adjunct Cultures Development
}

\author{
Maria Barbara Pisano $(\mathbb{D}$, Maura Deplano $(\mathbb{D}$, \\ Maria Elisabetta Fadda $(\mathbb{D}$, and Sofia Cosentino \\ Department of Medical Sciences and Public Health, University of Cagliari, Monserrato 09042, Italy \\ Correspondence should be addressed to Sofia Cosentino; scosenti@unica.it
}

Received 20 March 2019; Revised 3 June 2019; Accepted 13 June 2019; Published 8 July 2019

Guest Editor: Antonio Lourenco

Copyright ( 2019 Maria Barbara Pisano et al. This is an open access article distributed under the Creative Commons Attribution License, which permits unrestricted use, distribution, and reproduction in any medium, provided the original work is properly cited.

This work was performed to study the microbiota of raw goat's milk (67 samples) collected in different areas of Sardinia, in order to select autochthonous lactic acid bacteria $(\mathrm{LAB})$ strains for use in goat cheese manufacturing. Total mesophilic bacteria ranged between $10^{5}$ and $10^{7} \mathrm{cfu} / \mathrm{mL}$; mean counts of Enterobacteriaceae did not exceed $4 \log \mathrm{cfu} / \mathrm{mL}$ whereas those of $E$. coli and coagulasepositive staphylococci were lower than 1.5 and $2 \log \mathrm{ufc} / \mathrm{ml}$, respectively. Neither Salmonella spp. nor Listeria monocytogenes were recovered. The numbers of total $\mathrm{LAB}$ were in the range from $10^{4}$ to $10^{7} \mathrm{cfu} / \mathrm{mL}$ and mean yeasts counts varied between $10^{3}$ and $10^{5}$ $\mathrm{cfu} / \mathrm{mL}$. The most frequently isolated LAB species were Lactococcus lactis subsp. lactis and Lactobacillus paracasei. The presence of Enterococcus faecium was also noteworthy. The in vitro study of some functional characteristics related to technological properties of the strains belonging to these species allowed to point out some strains possessing good potential for use as adjunct or starter cultures in the production of cheese.

\section{Introduction}

Goat milk production is a crucial contributor to rural economy in many countries, especially in the Mediterranean and Middle East regions. Overall France, Greece, Italy, and Spain produce $49.2 \%$ of goat's milk in the Mediterranean region and $9.4 \%$ of the world goat's milk (FAOSTAT, 2018). In Italy, the population of dairy goats is reared mainly in extensive or semi-intensive systems. The size of the company is, on average, very small (36 goats/farm), with higher concentrations in Sicily (26.0\%) and Sardinia (21.5\%), followed by Piedmont, Lombardy, and Veneto, which together represent $22.2 \%$ of the total [1].

Due to the growing consumer interest in functional foods, goat's milk has gained popularity mainly because its high digestibility, high nutritional quality, low allergenicity, and potential nutraceutical properties $[2,3]$; therefore the production of goat cheeses has shown a growing trend in recent years. Goat milk is very present in Italian supermarkets, both in pasteurized and in UHT versions, but most of it is mainly processed into dairy products for national markets. In Sardinia, goat milk is almost exclusively used for cheeses' production, even if these products are not as famous as Sardinian ewe's cheeses. The diversification of goat milk production is essential but it is dependent on the development of new and valuable products.

Goat milk presents a rich and complex autochthonous microbiota, and its detailed knowledge is essential for the diversification of productions. This microbiota is responsible for the peculiar characteristics presented by fermented goat milk products and is composed by a wide range of microorganisms with different characteristics that can be potentially considered for use by the dairy industry. According to previous surveys, the main components of the autochthonous microbiota are lactic acid bacteria (LAB) belonging to the genera Lactococcus, Lactobacillus, Enterococcus, Leuconostoc, and Streptococcus [4-6]. LAB are known to produce a number of desirable substances that can improve the flavor, texture, 
nutritional value, shelf-life, and safety of foods [7], and the majority of the species possess the QPS status [8].

For safeguarding and promoting the traditional Sardinian goat dairy products, information on the microbial diversity of raw milk is the preliminary step to monitor the autochthonous microflora that certainly contribute to the typical organoleptic and quality characteristics of cheeses, in order to search for and select new strains with distinctive patterns of technological properties to be used in cheese production.

The objective of this study was to isolate and identify the dominant microbiota associated with raw goat's milk samples collected from dairy farms located in different areas of Sardinia. The strains belonging to the predominant LAB species were also analyzed by determining some technological properties relevant to their use as adjunct/starter cultures.

\section{Materials and Methods}

2.1. Sampling. A total of 67 samples of raw goat's milk collected from dairy farms located in different areas of Sardinia were analyzed. Each sample represented the pooled milk from one single milking of each herd. Samples were transported to the laboratory under refrigeration and analyzed on the same day.

2.2. Isolation and Identification of the Strains. Ten milliliters of milk was transferred to a sterile tube containing $90 \mathrm{~mL}$ of $2 \%(\mathrm{w} / \mathrm{v})$ sodium-citrate solution. Decimal dilutions were prepared in sterile solution of $2 \%(\mathrm{w} / \mathrm{v})$ sodium citrate and plated in duplicate on specific media to enumerate microbial groups.

Total mesophilic bacteria (TMB), Enterobacteriaceae, Escherichia coli, coagulase-positive staphylococci, presumptive enterococci, lactococci, and lactobacilli, were enumerated and identified according to Pisano et al. [9]. The identification of LAB was confirmed by polymerase chain reaction (PCR) with species-specific primers, as described in the literature [10-14]. Stock cultures were stored at $-20^{\circ} \mathrm{C}$ in De Man Rogosa Sharpe broth (MRS, Microbiol) containing $15 \%$ glycerol and propagated three times in MRS broth for activation before use in experiments.

The presence of foodborne pathogens Salmonella spp. and Listeria monocytogenes was also investigated. Twenty-five $\mathrm{mL}$ of sample was diluted in $225 \mathrm{~mL}$ of buffered peptone water, homogenized, and incubated for $18 \mathrm{~h}$ at $37^{\circ} \mathrm{C}$ for the detection of Salmonella spp., and another $25 \mathrm{~mL}$ of sample was diluted in Half-fraser broth, homogenized and then incubated for $24 \mathrm{~h}$ at $30^{\circ} \mathrm{C}$ for the detection of Listeria monocytogenes according to the ISO methods, respectively $[15,16]$.

Yeasts were enumerated on potato dextrose agar (PDA, Microbiol) with chloramphenicol (0.01\%) after incubation at $25^{\circ} \mathrm{C}$ for 5 days.

2.3. Technological Characteristics of LAB. Several technological properties were studied on 289 LAB isolates. Caseinolytic, lipolytic, and acidifying activity, citrate utilization, and acetoin production were evaluated as reported by Cosentino et al. [17]. Moreover, to evaluate the ability to coagulate milk, tubes with $10 \mathrm{~mL}$ of reconstituted skim milk (RSM, Oxoid, Basingstoke, UK) were inoculated with the strains, incubated in a thermostatic water bath at $30^{\circ} \mathrm{C}$, and observed after $24 \mathrm{~h}$ for milk coagulation, while to assess the activity of the $\beta$-galactosidase enzyme, one colony of each isolate was emulsified in a tube containing an ONPG (o-nitrophenyl- $\beta$-d-galactopyranoside) disk (Fluka, Buchs, Switzerland) and $1 \mathrm{~mL}$ sterile saline. The tubes were incubated at $37^{\circ} \mathrm{C}$, and the yellow staining (positive reaction) was observed within $6 \mathrm{~h}$. All tests were performed in duplicate.

Finally, the LAB strains were screened for the antibacterial activity against the following indicator strains: Listeria monocytogenes ATCC 7644, Escherichia coli O157:H7 ATCC 35150, Enterococcus faecalis ATCC 19433, Lactobacillus plantarum DSMZ 20174, and the bacteriocin-sensitive Lactobacillus sakei subsp. sakei DSMZ 20017, using an agar spot test as reported by Pisano et al. [18].

2.4. Statistical Analysis. Microbial counts were calculated as the number of colony-forming units (cfu) per milliliter of sample and reported as $\log _{10} \mathrm{cfu} / \mathrm{mL}$. Calculations of standard deviations (SD) were also performed. The mean microbial counts of milk samples collected from two geographical areas of Sardinia were analyzed by Student's t-test using the software GraphPad Prism Statistics vs. 3.00. The significant level of test was set at $\mathrm{P}<0.05$.

\section{Results and Discussion}

3.1. Isolation and Identification of the Strains. Figure 1 shows mean values (expressed as $\log _{10} \mathrm{cfu} / \mathrm{mL}$ ) and standard deviations for the main microbial groups isolated from the milk samples analyzed. Total mesophilic bacteria (TMB) ranged between $10^{5}$ and $10^{7} \mathrm{cfu} / \mathrm{mL}$ and were significantly higher in samples from north Sardinia. Mean counts of Enterobacteriaceae did not exceed $4 \log \mathrm{cfu} / \mathrm{mL}$ whereas those of $E$. coli and coagulase-positive staphylococci were lower than 1.5 and $2 \log \mathrm{cfu} / \mathrm{ml}$, respectively. These values are within the range of those reported in previous works for raw goat's milk used for the production of traditional cheeses in Europe $[6,19]$. Although about $50 \%$ of milk samples showed total viable counts above the maximum value established by Italian legislation for raw milk intended for further processing $\left(5 \times 10^{5} \mathrm{cfu} / \mathrm{mL}\right.$; Regulation EC $\left.853 / 2004\right)$, it is important to note that LAB accounted for the majority of the microflora, in agreement with the results of the above-mentioned works. However, still there are chances that the microbial load might be enhanced if storage and handling conditions are not appropriate. The presence of Enterobacteriaceae, E. coli, and coagulase-positive staphylococci in milk is an indicator of unsanitary production and/or improper milking procedures. Millogo et al. [20] pointed out that the differences detected in the microbial load of raw goat's milk samples collected from two farms were related to extrinsic factors such as hygienic conditions during milk handling, season, and geographical location of farms. In our study, all samples were collected 


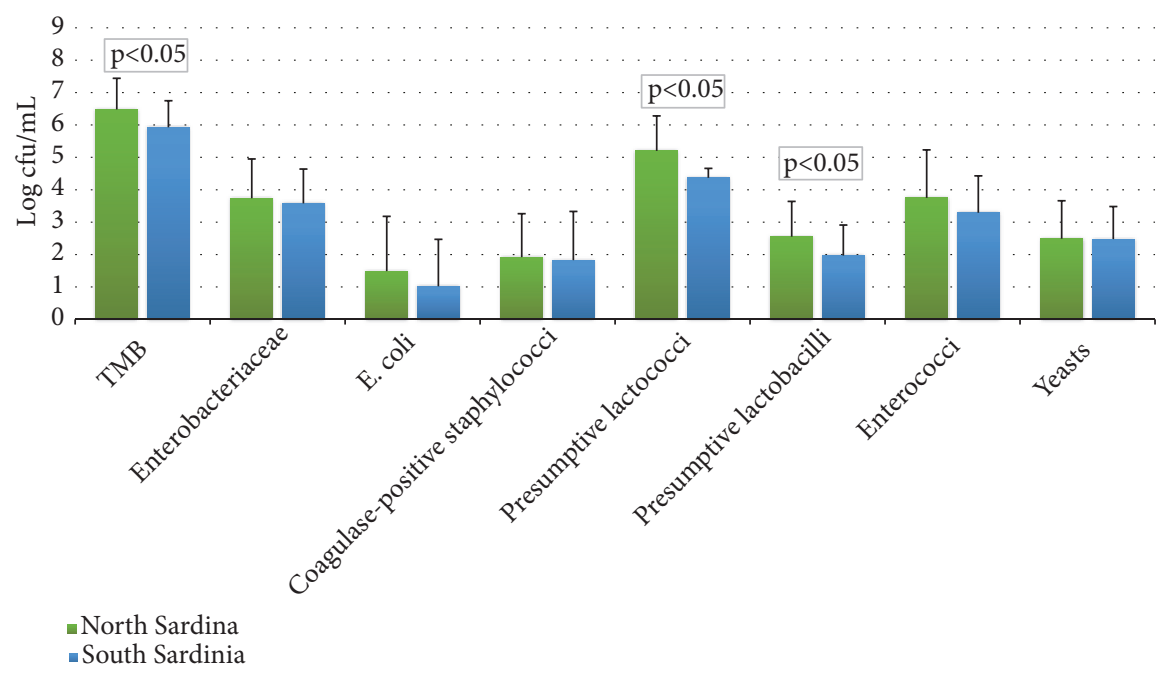

FIGURE 1: Mean counts \pm SD of main microbial groups isolated from raw goat's milk samples collected from dairy farms located in North and South Sardinia.

TABLE 1: Distribution of LAB species in raw goat's milk samples.

\begin{tabular}{|c|c|c|c|}
\hline Genus & Species & Frequency (\%) & $\begin{array}{c}\text { N. of strains } \\
(289)\end{array}$ \\
\hline \multirow[t]{4}{*}{ Lactococcus } & Lc. lactis subsp. lactis & 15.6 & 45 \\
\hline & Lc. raffinolactis & 6.2 & 18 \\
\hline & Lc. plantarum & 5.9 & 17 \\
\hline & Lc lactis subsp. cremoris & 1.7 & 5 \\
\hline \multirow[t]{4}{*}{ Lactobacillus } & L. paracasei & 14.5 & 42 \\
\hline & L. curvatus & 6.9 & 20 \\
\hline & L. plantarum & 5.9 & 17 \\
\hline & L. brevis & 5.2 & 15 \\
\hline Pediococcus & P. pentosaceus & 7.3 & 21 \\
\hline \multirow[t]{2}{*}{ Leuconostoc } & Ln. mesenteroides subsp. mesenteroides & 3.1 & 9 \\
\hline & Ln. mesenteroides subsp. dextranicum & 1.7 & 5 \\
\hline Streptococcus & S. salivarius subsp. thermophilus & 2.4 & 7 \\
\hline \multirow[t]{4}{*}{ Enterococcus } & E. faecium & 11.4 & 33 \\
\hline & E. faecalis & 7.6 & 22 \\
\hline & E. durans & 2.8 & 8 \\
\hline & E. avium & 1.7 & 5 \\
\hline
\end{tabular}

in winter and no statistically significant differences were observed for contaminants' counts in samples from north and south Sardinia, while the milking process was performed by hand (by the farmer) in about one-third of the samples; hence the transmission of microorganisms might have occurred.

In relation to the presence of pathogenic species, it is important to note that neither Salmonella spp. nor Listeria monocytogenes were recovered from milk samples analyzed during the present study.

The numbers of total LAB were in the range from $10^{4}$ to $10^{7} \mathrm{cfu} / \mathrm{mL}$, and significantly higher $(\mathrm{p}<0.05)$ counts were detected in raw milk samples collected in north Sardinia. Enterococci counts ranged between $10^{3}$ and $10^{5} \mathrm{cfu} / \mathrm{mL}$. The numbers of presumptive lactococci were higher than those of presumptive lactobacilli. Similar LAB counts were reported by Perin and Nero [5] and de Almeida et al. [3] in Brazilian raw goat's milk samples.

No significant difference was detected in the means of total yeast counts, ranging between $10^{3}$ and $10^{5} \mathrm{cfu} / \mathrm{mL}$. Even if few studies have been carried out on the total count of yeasts in goat's milk, our data confirmed their low presence [21, 22].

The distribution of LAB species found in raw goat's milk samples is summarized in Table 1.

Of the 308 isolates obtained from M17, MRS, and Kenner Fecal Streptococcus (KF) agar plates, 289 were grouped into six genera, Lactococcus and Lactobacillus being the dominant ones, and 16 species, on the basis of their physiological and biochemical features, while 19 did not grow in subsequent 
TABLE 2: Functional characteristics of technological interest for prevalent LAB species isolated from goat milk.

\begin{tabular}{lcccc}
\hline & \multicolumn{2}{c}{$\begin{array}{c}\text { Lc. lactis subsp. lactis } \\
\text { (no. of strains 45) }\end{array}$} & $\begin{array}{c}\text { Enterococcus faecium } \\
\text { (no. of strains 33) }\end{array}$ & $\begin{array}{c}\text { Lb. paracasei } \\
\text { (no. of strains 42) }\end{array}$ \\
\hline Casein hydrolysis & 37.7 & 27.2 & 28.6 \\
\hline Citrate utilization & 20 & 30.3 & 88 \\
\hline Lipolytic activity & & 0 & 0 & 0 \\
\hline Acetoin production & $\mathrm{pH}(0-1)$ & 0 & 6.1 & 21.4 \\
\hline & $\Delta \mathrm{pH}(1-2)$ & 37.7 & 42.4 & 83.3 \\
Acidifying activity & $\Delta \mathrm{pH}(>2)$ & 6.7 & 51.5 & 16.7 \\
\hline Milk coagulation & & 55.5 & 6.1 & 0 \\
\hline B-galactosidase activity & & 73.3 & 18.1 & 21.4 \\
\hline
\end{tabular}

cultures. The majority of LAB isolates were characterized as cocci (195), which have been reported to be the dominant LAB in goat's milk by several authors $[4,5,23]$. The most frequently isolated species was Lc. lactis subsp. lactis, representing $15.6 \%$ of the total isolates, followed by L. paracasei which accounted for $14.5 \%$. Lc. raffinolactis was the second most frequently recovered species among Lactococcus isolates, followed by $L c$. plantarum and Lc. lactis subsp. cremoris. Tetrad-forming cocci belonging to $P$. pentosaceus were also recovered, while Leuconostoc and Streptococcus salivarius subsp. thermophilus were only sporadically isolated. Besides L. paracasei, facultatively heterofermentative lactobacilli were represented, in order of frequency, by the species L. curvatus and L. plantarum, while L. brevis was the only species isolated among obligately heterofermentative lactobacilli. The presence of enterococci, mainly represented by E. faecium and E. faecalis, was also noteworthy. Their recovery in raw milk could be due to faecal contamination, either directly or indirectly through contaminated water sources, milking equipment and bulk storage tanks [24]. Other authors have observed a similar distribution of LAB in raw goat's milk and cheeses $[4,5,25]$. Our results finding Lc. lactic subsp. lactis as the dominant species in raw goat's milk are in line with those reported by some authors $[5,23]$, but in contrast with others reporting lactobacilli as the dominant microbiota $[4,26]$. The differences in dominant LAB could be attributed to several factors such as different goat breeds, hygienic procedure of milking, and sampling period [26, 27]. The species $L$. paracasei has been previously isolated from both goat milk and dairy farms in Brazil [3] and raw goat milk cheeses $[28,29]$.

3.2. Technological Characterization of LAB. Table 2 shows the results of a preliminary technological characterization of the strains belonging to the predominant LAB species isolated from raw goat's milk, namely, Lc. lactis subsp. lactis, E. faecium and $L$. paracasei. The identification of strains belonging to these species was confirmed by species-specific PCR (data not shown).

As for the acidifying ability, expressed as decrease in $\mathrm{pH}$ with respect to the value of noninoculated control milk
(pH 6.5) after $24 \mathrm{~h}$ of incubation at $30^{\circ} \mathrm{C}$ in RSM, the majority of Lc. lactis subsp. lactis strains (25) were found to be good acidifiers, showing a $\mathrm{pH}$ drop higher than 2 units after 24 h, while L. paracasei and E. faecium isolates were slow acid producers, since none or few strains were able to decrease the $\mathrm{pH}$ more than 2 units, respectively. The inter- and intraspecies variation in acidification activity were in agreement with the literature [30-32]. Skim milk agar is an effective and rapid medium to detect the extracellular cell-bound proteinases as shown by a clear zone surrounding the colonies. The application of this technique to the 120 strains analyzed showed a good percentage of strains (32\%) able to hydrolyze casein, the most active species being Lc. lactis subsp. lactis. Some caseinolytic activity was also observed in L. paracasei strains, as reported by Meng et al. [29]. Proteolytic enzymes play a major role in the fermentation of dairy products [33], since the hydrolysis of milk protein by LAB strains results in an enhanced amount of free amino groups and peptides which are important for microbial growth and as precursor for aroma development during cheeses ripening; however, high proteolytic activity is not always desirable because it can produce large amounts of bitter peptides and other undesirable compounds, or even excessive casein hydrolysis leading to an exceedingly soft final product $[17,34]$.

None of the strains produced lipolytic reactions on tributyrin agar, in agreement with the results of Meng et al. [29]. Utilization of citrate seemed to be a characteristic of $L$. paracasei strains. A low proportion of these citrate positive strains were also able to produce acetoin. All these properties are confirmed to be strain dependent as they varied significantly among the strains within the same species $[4,17,35]$. The low acidifying and caseinolytic activity as well as the absence of lipolytic activity observed in our lactobacilli and enterococci strains suggest their possible role as adjunct cultures for cheese production, rather than as starters. The majority of $L c$. lactis subsp. lactis isolates (33) were able to coagulate skim milk after $24 \mathrm{~h}$ at $30^{\circ} \mathrm{C}$ revealing, together with their high acidifying ability, their potential as starters in the production of fermented dairy products. In accord with other studies [36, 37], all Lc. lactis subsp. lactis and L. paracase $i$ and the majority of E. faecium strains exhibited a 
TABLE 3: Distribution of antibacterial activity in prevalent LAB species isolated from goat milk (\% of strains).

\begin{tabular}{|c|c|c|c|c|c|c|c|c|c|}
\hline \multirow{3}{*}{ Target strains } & \multicolumn{3}{|c|}{$\begin{array}{l}\text { Lc. lactis subsp. lactis } \\
\text { (45 strains) }\end{array}$} & \multicolumn{3}{|c|}{$\begin{array}{l}\text { E. faecium } \\
\text { (33 strains) }\end{array}$} & \multicolumn{3}{|c|}{$\begin{array}{l}\text { Lb. paracasei } \\
\text { (42 strains) }\end{array}$} \\
\hline & 0 & $3-0.5$ & $6-4$ & 0 & $3-0.5$ & $6-4$ & 0 & $3-0.5$ & $6-4$ \\
\hline & \multicolumn{9}{|c|}{ diameter of inhibition zone (mm) } \\
\hline $\begin{array}{l}\text { L. monocytogenes } \\
\text { ATCC } 7644\end{array}$ & 51.1 & 20 & 28.9 & 63.6 & 15.2 & 21.2 & 0 & 0 & 100 \\
\hline $\begin{array}{l}\text { E. coli O157:H7 } \\
\text { ATCC } 35150\end{array}$ & 22.3 & 37.7 & 40 & 33.3 & 51.5 & 15.2 & 42.8 & 4.8 & 52.4 \\
\hline $\begin{array}{l}\text { E. faecalis ATCC } \\
19433\end{array}$ & 68.9 & 31.1 & 0 & 6 & 6 & 88 & 71.4 & 28.6 & 0 \\
\hline $\begin{array}{l}\text { L. plantarum } \\
\text { DSM } 20174\end{array}$ & 84.4 & 8.9 & 6.7 & 0 & 3 & 97 & 78.6 & 21.4 & 0 \\
\hline $\begin{array}{l}\text { L. sakei subsp. sakei } \\
\text { DSM } 20017\end{array}$ & 89 & 11 & 0 & 0 & 3 & 97 & 66.7 & 33.3 & 0 \\
\hline
\end{tabular}

strong $\beta$-galactosidase activity which is the main enzymatic activity responsible for the hydrolysis of lactose. This activity is relevant not only for its technological importance but also from a probiotic perspective, because it can prevent and reduce lactose intolerance.

The antagonistic effect of LAB dairy strains on pathogenic microorganisms could be used for expanding the range of healthful dairy foods. LAB originally isolated from raw milk or artisanal dairy products are probably the best candidate for improving the microbiological safety of these foods, because they are well adapted to the conditions of the substrate.

In this study the 120 strains belonging to the predominant species were preliminarily screened for antimicrobial activity against five indicator strains, including two well recognized foodborne pathogens, by means of an agar spot method (Table 3). Several strains were found to produce an inhibition zone of at least $0.5 \mathrm{~mm}$ against the indicators tested. The strongest inhibitory activity was found towards the foodborne pathogens Listeria monocytogenes ATCC 7644 and E. coli O157:H7 ATCC 35150 by L. paracasei and Lc. lactis subsp. lactis strains. E. faecium was more active against E. faecalis ATCC 19433, L. plantarum DSM 20174, and the bacteriocin-sensitive strain L. sakei subsp. sakei DSMZ 20017. Our lactococci and lactobacilli strains could therefore be considered potential candidates for control of pathogens in dairy products. Several studies have demonstrated the LAB strains possess considerable inhibitory activity against pathogens and spoilage microorganisms in food (see review by de Sousa and Dias, 2017) [38] by the production of antimicrobial substances, including organic acids, hydrogen peroxide, and bacteriocins $[32,39]$. Our strains are currently under investigation to further elucidate their antimicrobial properties.

\section{Conclusions}

Although the characterization of raw goat's milk in terms of LAB composition and technological activity has been carried out by several authors in different parts of the world [3, 4, $6,19,23,26]$, to the best of our knowledge this is the first study investigating both the biodiversity and technological properties of LAB strains isolated from Sardinian goat's milk samples.

This work was performed to study the microbiota of raw goat's milk collected in different areas of Sardinia, in order to select LAB strains for use as adjunct or starter cultures in the manufacturing of both artisanal and industrial goat's milk cheeses. This local raw milk could serve as source for natural LAB strains, well adapted to milk and cheese environment which can contribute to the safety, quality, and development of typical taste and flavor of the final product.

Predominance of Lc. lactis subsp. lactis and L. paracasei species suggests their important role in manufacturing and ripening of goat's milk cheeses. The in vitro study of some functional characteristics related to technological properties allowed to point out some strains belonging to these predominant species possessing good potential for use in the production of cheese. In particular, some $L c$. lactis subsp. lactis strains could be an appropriate starter for goat cheese manufacture, while the L. paracasei strains with $\beta$-galactosidase activity could be used as an adjunct to complement the activities present in the starter and influence flavor development during cheese ripening.

Further studies will be carried out to determine the growth dynamics and behaviour of the selected strains in the cheese environment and their potential probiotic properties.

\section{Data Availability}

The data used to support the findings of this study are available from the corresponding author upon request.

\section{Conflicts of Interest}

The authors declare that there are no conflicts of interests regarding the publication of this paper.

\section{Acknowledgments}

This work was partially supported by grants from Università di Cagliari (Progetti FIR, 2016). 


\section{References}

[1] G. Pulina, M. J. Milán, M. P. Lavín et al., "Invited review: Current production trends, farm structures, and economics of the dairy sheep and goat sectors," Journal of Dairy Science, vol. 101, no. 8, pp. 6715-6729, 2018.

[2] G. F. W. Haenlein, "Goat milk in human nutrition," Small Ruminant Research, vol. 51, no. 2, pp. 155-163, 2004.

[3] W. L. G. de Almeida Júnior, Í. D. S. Ferrari, J. V. de Souza, C. D. A. da Silva, M. M. da Costa, and F. S. Dias, "Characterization and evaluation of lactic acid bacteria isolated from goat milk," Food Control, vol. 53, pp. 96-103, 2015.

[4] A. Badis, D. Guetarni, B. Moussa-Boudjemâa, D. E. Henni, M. E. Tornadijo, and M. Kihal, "Identification of cultivable lactic acid bacteria isolated from Algerian raw goat's milk and evaluation of their technological properties," Food Microbiology, vol. 21, no. 3, pp. 343-349, 2004.

[5] L. M. Perin and L. A. Nero, "Antagonistic lactic acid bacteria isolated from goat milk and identification of a novel nisin variant Lactococcus lactis," BMC Microbiology, vol. 14, no. 1, 2014.

[6] A. Picon, S. Garde, M. Ávila, and M. Nuñez, "Microbiota dynamics and lactic acid bacteria biodiversity in raw goat milk cheeses," International Dairy Journal, vol. 58, pp. 14-22, 2016.

[7] S. Rodgers, "Novel applications of live bacteria in food services: probiotics and protective cultures," Trends in Food Science \& Technology, vol. 19, no. 4, pp. 188-197, 2008.

[8] EFSA Journal 14:4522, Appendix: The 2013 updated list of QPS Status recommended biological agents in support of EFSA risk assessments - 4th revision, 2016.

[9] M. B. Pisano, M. E. Fadda, M. Deplano et al., "Microbiological and chemical characterization of fiore sardo, a traditional Sardinian ewes' cheese," International Journal of Dairy Technology, vol. 59, pp. 160-178, 2006.

[10] S. Dutka-Malen, S. Evers, and P. Courvalin, "Detection of glycopeptide resistance genotypes and identification to the species level of clinically relevant enterococci by PCR," Journal of Clinical Microbiology, vol. 33, no. 1, pp. 24-27, 1995.

[11] M. Drake, C. L. Small, K. D. Spence, and B. G. Swanson, "Rapid detection and identification of Lactobacillus spp. in dairy products by using the polymerase chain reaction," Journal of Food Protection, vol. 59, no. 10, pp. 1031-1036, 1996.

[12] F. Quere, A. Deschamps, and M. C. Urdaci, "DNA probe and PCR-specific reaction for Lactobacillus plantarum," Journal of Applied Microbiology, vol. 82, no. 6, pp. 783-790, 1997.

[13] E. Knijff, F. Dellaglio, A. Lombardi, C. Andrighetto, and S. Torriani, "Rapid identification of Enterococcus durans and Enterococcus hirae by PCR with primers targeted to the ddl genes," Journal of Microbiological Methods, vol. 47, no. 1, pp. 3540, 2001.

[14] Z. Pu, M. Dobos, G. Limsowtin, and I. Powell, "Integrated polymerase chain reaction-based procedures for the detection and identification of species and subspecies of the Gram-positive bacterial genus Lactococcus," Journal of Applied Microbiology, vol. 93, no. 2, pp. 353-361, 2002.

[15] ISO, Microbiology of Food And Animal Feeding Stuffs. Horizontal Method for The Detection of Salmonella spp. ISO Standard 6579:2002, International Organization for Standardization, Geneva, Switzerland, 2002.

[16] ISO, Microbiology of the food chain. Horizontal method for the detection and enumeration of Listeria monocytogenes and
Listeria spp. Part 1: Detection method. ISO Standard 112901:1996+A1, International Organization for Standardization, Geneva, Switzerland, 2004.

[17] S. Cosentino, M. B. Pisano, A. Corda, M. E. Fadda, and C. Piras, "Genotypic and technological characterization of enterococci isolated from artisanal Fiore Sardo cheese," Journal of Dairy Research, vol. 71, no. 4, pp. 444-450, 2004.

[18] M. B. Pisano, S. Viale, S. Conti et al., "Preliminary evaluation of probiotic properties of Lactobacillus strains isolated from sardinian dairy products," BioMed Research International, vol. 2014, Article ID 286390, 9 pages, 2014.

[19] F. Morgan, T. Massouras, M. Barbosa et al., "Characteristics of goat milk collected from small and medium enterprises in Greece, Portugal and France," Small Ruminant Research, vol. 47, no. 1, pp. 39-49, 2003.

[20] V. Millogo, K. S. Sjaunja, G. A. Ouédraogo, and S. Agenäs, "Raw milk hygiene at farms, processing units and local markets in Burkina Faso," Food Control, vol. 21, no. 7, pp. 1070-1074, 2010.

[21] C. Callon, F. Duthoit, C. Delbès et al., "Stability of microbial communities in goat milk during a lactation year: Molecular approaches," Systematic and Applied Microbiology, vol. 30, no. 7, pp. 547-560, 2007.

[22] E. Delavenne, J. Mounier, F. Déniel, G. Barbier, and G. Le Blay, "Biodiversity of antifungal lactic acid bacteria isolated from raw milk samples from cow, ewe and goat over one-year period," International Journal of Food Microbiology, vol. 155, no. 3, pp. 185-190, 2012.

[23] H. Tormo, D. Ali Haimoud Lekhal, and C. Roques, "Phenotypic and genotypic characterization of lactic acid bacteria isolated from raw goat milk and effect of farming practices on the dominant species of lactic acid bacteria," International Journal of Food Microbiology, vol. 210, pp. 9-15, 2015.

[24] R. Gelsomino, M. Vancanneyt, S. Condon, J. Swings, and T. Cogan, "Enterococcal diversity in the environment of an Irish Cheddar-type cheesemaking factory," International Journal of Food Microbiology, vol. 71, no. 2-3, pp. 177-188, 2001.

[25] M. Nikolic, A. Terzic-Vidojevic, B. Jovcic et al., "Characterization of lactic acid bacteria isolated from Bukuljac, a homemade goat's milk cheese," International Journal of Food Microbiology, vol. 122, no. 1-2, pp. 162-170, 2008.

[26] G. Makete, O. A. Aiyegoro, and M. S. Thantsha, "Isolation, identification and screening of potential probiotic bacteria in milk from south african saanen goats," Probiotics and Antimicrobial Proteins, vol. 9, no. 3, pp. 246-254, 2017.

[27] E. Delavenne, J. Mounier, K. Asmani, J.-L. Jany, G. Barbier, and G. Le Blay, "Fungal diversity in cow, goat and ewe milk," International Journal of Food Microbiology, vol. 11, no. 2, pp. 247251, 2011.

[28] I. Sánchez, S. Seseña, J. M. Poveda, L. Cabezas, and L. Palop, "Phenotypic and genotypic characterization of lactobacilli isolated from Spanish goat cheeses," International Journal of Food Microbiology, vol. 102, no. 3, pp. 355-362, 2005.

[29] Z. Meng, L. Zhang, L. Xin, K. Lin, H. Yi, and X. Han, "Technological characterization of Lactobacillus in semihard artisanal goat cheeses from different Mediterranean areas for potential use as nonstarter lactic acid bacteria," Journal of Dairy Science, vol. 101, no. 4, pp. 2887-2896, 2018.

[30] P. Nieto-Arribas, S. Seseña, J. Poveda, L. Palop, and L. Cabezas, "Genotypic and technological characterization of Lactococcus lactis isolates involved in processing of artisanal Manchego cheese," Journal of Applied Microbiology, vol. 107, no. 5, pp. 15051517, 2009. 
[31] A. Marroki, M. Zúñiga, M. Kihal, and G. Pérez-Martínez, "Characterization of lactobacillus from algerian goat's milk based on phenotypic, $16 \mathrm{~S}$ rDNA sequencing and their technological properties," Brazilian Journal of Microbiology, vol. 42, no. 1, pp. 158-171, 2011.

[32] S. Schirru, S. D. Todorov, L. Favaro et al., "Sardinia goat's milk as a source of bacteriocinogenic potential protective cultures," Food Control, vol. 25, no. 1, pp. 309-320, 2012.

[33] A. K. Puniya, Fermented milk and dairy products, CRC Press, Boca Raton, Fla, USA, 2015.

[34] M. G. Bonomo and G. Salzano, "Genotypic and technological diversity of Leuconostocmesenteroides and Lactobacillus paracasei spp. paracasei strains for use as adjunct starters cultures in Pecorino di Filiano cheese," International Journal of Dairy Technology, vol. 66, no. 3, pp. 402-409, 2013.

[35] L. M. Perin, S. Belviso, B. Dal Bello, L. A. Nero, and L. Cocolin, "Technological properties and biogenic amines production by bacteriocinogenic lactococci and enterococci strains isolated from raw goat's milk," Journal of Food Protection, vol. 80, no. 1, pp. 151-157, 2017.

[36] K. M. Santos, A. D. Vieira, H. O. Salles et al., "Safety, beneficial and technological properties of Enterococcus faecium isolated from Brazilian cheeses," Brazilian Journal of Microbiology, vol. 46, no. 1, pp. 237-249, 2015.

[37] R. C. S. Castro, A. P. D. de Oliveira, E. A. R. de Souza et al., "Lactic acid bacteria as biological control of Staphylococcus aureus in coalho goat cheese," Food Technology \& Biotechnology, vol. 56, pp. 431-440, 2018.

[38] J. Viana de Souza and F. Silva Dias, "Protective, technological, and functional properties of select autochthonous lactic acid bacteria from goat dairy products," Current Opinion in Food Science, vol. 13, pp. 1-9, 2017.

[39] W. H. Holzapfel, "Biological preservation of foods with reference to protective cultures, bacteriocins and food-grade enzymes," International Journal of Food Microbiology, vol. 24, no. 3, pp. 343-362, 1995. 


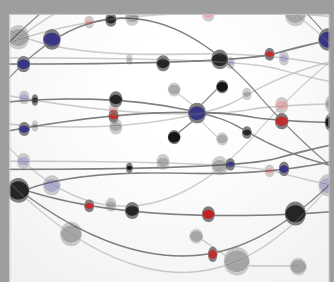

The Scientific World Journal
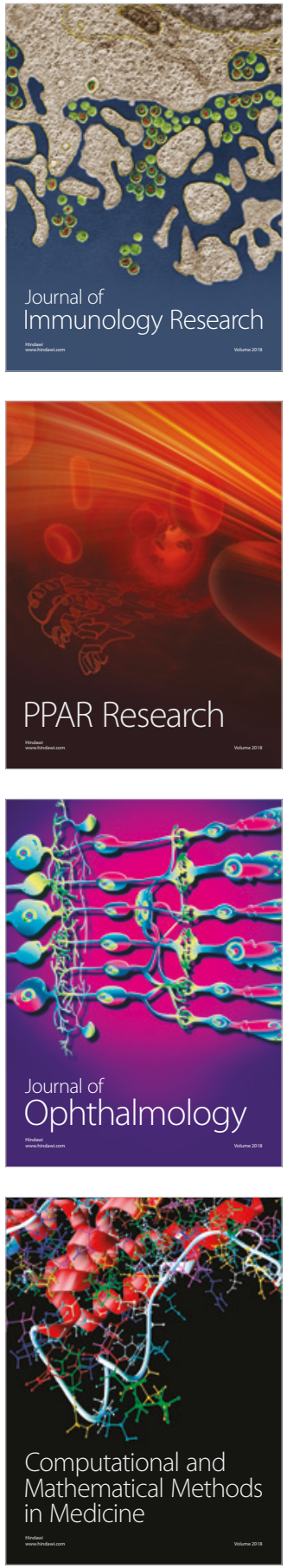

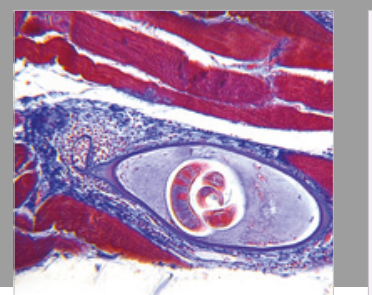

Gastroenterology Research and Practice

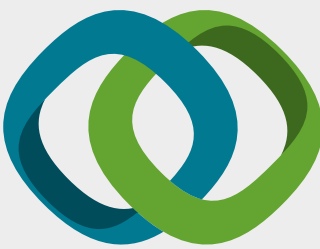

\section{Hindawi}

Submit your manuscripts at

www.hindawi.com
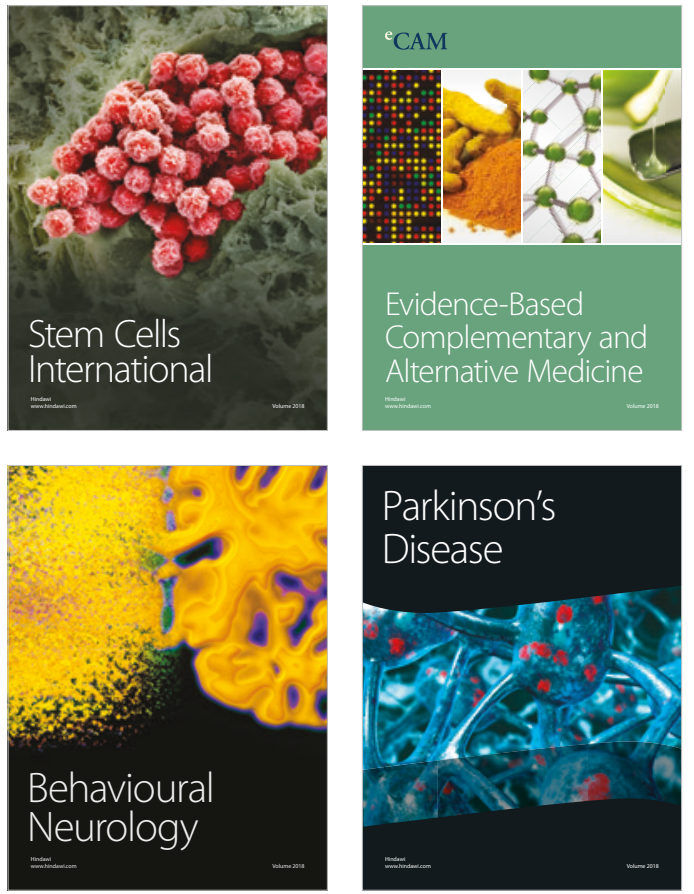

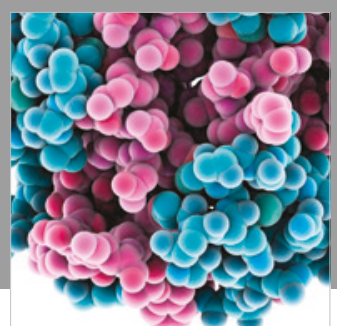

ournal of

Diabetes Research

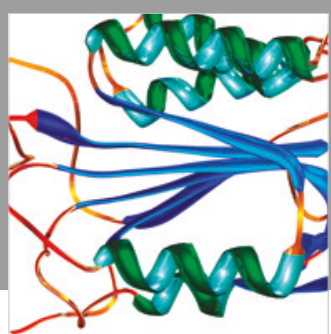

Disease Markers
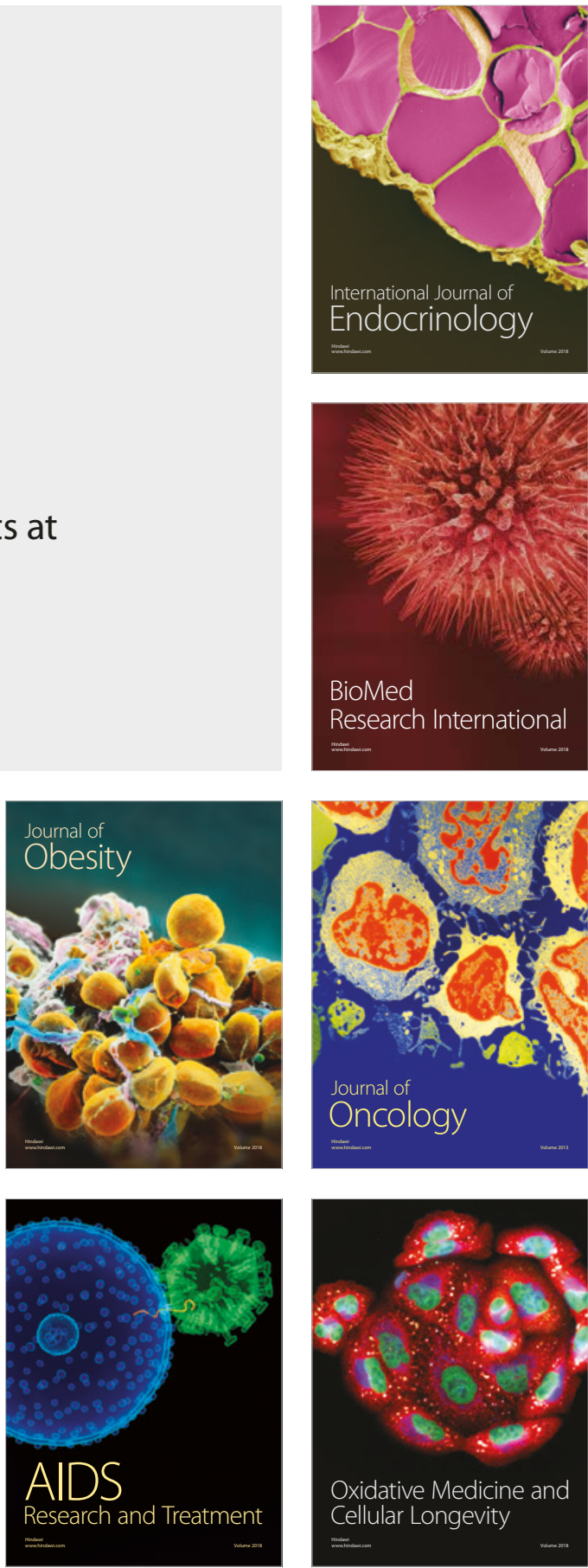